Hiroshi Mitsuyasu • Naotsugu Hirata $\cdot$ Yasuyoshi Sakai

Hiroki Shibata $\cdot$ Yasuhiko Takeda $\cdot$ Hideaki Ninomiya

Hiroaki Kawasaki • Nobutada Tashiro

Yasuyuki Fukumaki

\title{
Association analysis of polymorphisms in the upstream region of the human dopamine D4 receptor gene (DRD4) with schizophrenia and personality traits
}

Received: August 28, 2000 / Accepted: October 25, 2000

\begin{abstract}
The human dopamine D4 receptor (DRD4) is of major interest in molecular studies of schizophrenia and personality traits. We examined the association of schizophrenia and polymorphisms in the upstream region of the $D R D 4$ gene $(-768 \mathrm{G}>\mathrm{A}$ in the negative modulator region; $-521 \mathrm{C}>\mathrm{T},-376 \mathrm{C}>\mathrm{T}$, and $-291 \mathrm{C}>\mathrm{T}$ in the cell typespecific promoter region; and $-616 \mathrm{C}>\mathrm{G}$ between the two regions) in 208 schizophrenic patients and 210 normal controls. No significant difference in genotype and allele frequencies was observed between the two groups, indicating that these polymorphisms do not make a major contribution to the pathogenesis of schizophrenia. We also studied the association of polymorphisms in the upstream region and a 48-bp repeat polymorphism in exon III of the DRD4 gene with personality traits in 173 Japanese individuals who completed the temperament and character inventory (TCI). The $-768 \mathrm{G}>\mathrm{A}$ polymorphism was significantly associated with reward dependence $(P=0.044)$, while no significant association was observed between novelty seeking and polymorphisms in the upstream region or the exon III repeat polymorphism of the $D R D 4$ gene.
\end{abstract}

Key words Dopamine D4 receptor · Polymorphism Association $\cdot$ Schizophrenia $\cdot$ Personality trait $\cdot$ TCI

\section{Introduction}

The dopaminergic neurotransmission system attracts attention because of its possible involvement in the etiology of several psychotic disorders and personality traits. Five dis-

H. Mitsuyasu $\cdot$ N. Hirata $\cdot$ Y. Sakai $\cdot$ H. Shibata $\cdot$ Y. Takeda

Y. Fukumaki $(\bowtie)$

Division of Disease Genes, Institute of Genetic Information, Kyushu

University, 3-1-1 Maidashi, Higashi-ku, Fukuoka 812-8582, Japan

Tel. +81-92-642-6168; Fax +81-92-632-2375

e-mail: yfukumak@gen.kyushu-u.ac.jp

H. Mitsuyasu $\cdot$ Y. Takeda $\cdot$ H. Ninomiya $\cdot$ H. Kawasaki $\cdot$ N. Tashiro Department of Neuropsychiatry, Graduate School of Medical

Sciences, Kyushu University, Fukuoka, Japan tinct dopamine receptor genes have been identified, and have been classified into D1-like receptors (D1 and D5) and D2-like receptors (D2, D3, and D4) according to their structural and pharmacological characteristics. Of these, the human dopamine D4 receptor (DRD4) is considered to be a candidate for involvement in schizophrenia and personality traits. $D R D 4$ mRNA expression was observed in the human frontal cortex, amygdala, thalamus, cerebellum, pituitary, entorhinal cortex, and hippocampus (Hartman and Lanau 1997). An autoradiographic study with a D4selective agent, $\left[{ }^{3} \mathrm{H}\right]$ NGD-94-1, suggested high levels of radioligand binding in the normal post-mortem human hippocampus and entorhinal cortex, and low levels in the caudate, putamen, nucleus accumbens, and substantia nigra (Tarazi and Baldessarini 1999). Clozapine, an antipsychotic for the management of socially withdrawn and treatmentresistant schizophrenics, has a relatively high affinity to DRD4 (Van Tol et al. 1991). The density of DRD4 was sixfold elevated in the brains of schizophrenic patients (Seeman et al. 1993). Elevation of DRD4 mRNA level was found in the frontal cortex of schizophrenic patients postmortem compared with levels in controls (Stefanis et al. 1998). These observations suggest that allelic variations affecting transcription levels of the DRD4 gene could be involved in the pathogenesis of schizophrenia.

Twin studies demonstrate that personality traits, measured by self-report questionnaires such as the tridimensional personality questionnaire (TPQ), are partially inherited, and $30 \%-60 \%$ of observed variance can be accounted for genetically (Cloninger 1987; Bouchard 1994). In the temperament and character inventory (TCI) that was developed from the TPQ, personality traits are divided into four temperaments: novelty seeking; harm avoidance; reward dependence; and persistence, based on a biopsychosocial view of personality. Association of the exon III repeat polymorphism in the DRD4 gene with the personality trait of novelty seeking was reported in 1996 (Ebstein et al. 1996; Benjamin et al. 1996); however, conflicting results were also reported (Paterson et al. 1999). Association analysis of polymorphisms in the upstream region of the $D R D 4$ gene with personality 
traits may be useful to evaluate this interesting observation.

Our previous study of DRD4 gene expression, using cultured cells, revealed that the region between -591 and -123 relative to the first nucleotide of the initiation codon contains the promoter of the DRD4 gene, which is responsible for the cell type-specific expression of the gene, and the negative modulator region is located between -770 and -679 (Kamakura et al. 1997). We have identified ten polymorphisms in the upstream region of the $D R D 4$ gene, spanning the negative modulator and the cell type-specific promoter regions (Mitsuyasu et al. 1999). In the present study, we investigated the association between schizophrenia and polymorphisms in the upstream region of the $D R D 4$ gene. We also examined the association between personality traits and polymorphisms in the upstream region and an exon III repeat polymorphism of the $D R D 4$ gene.

\section{Subjects and methods}

\section{Subjects}

The Ethics Committee of the Faculty of Medicine of Kyushu University approved the study protocol. Two hundred and eight schizophrenic patients (116 men and 92 women) were recruited from seven hospitals in the Fukuoka area, one hospital in the Nagasaki area, and one hospital in the Oita area, Japan. The diagnosis of schizophrenia was made according to DSM-IV criteria (American Psychiatric Association, 1994). The mean age of the schizophrenic patients was 51.5 years (SD, 13.9). There were 210 controls (120 men were recruited from the personnel of the Japanese Self-Defense Forces and 90 women volunteers were recruited from the staff of two hospitals). The mean age of the controls was 50.5 years (SD, 5.0). In the association study for personality traits, 173 subjects (all men; mean age, 52.2 years; SD, 0.8) were recruited from the Japanese Self-Defense Forces personnel. All patients and the control subjects gave their informed consent. All patients and controls were ethnically Japanese.

\section{Genotyping}

Genomic DNA was extracted from leukocytes by salting out with saturated sodium chloride solution, as described by Lahiri and Nurnberger (1991). The fragment spanning between $-947 \mathrm{bp}$ and $-156 \mathrm{bp}$ of the $D R D 4$ gene was amplified by polymerase chain reaction (PCR), using the sense primer, D4neg3 (5'-CAGGTCACAGGTCACCCCT CTT-3', -947/-926) and the antisense primer, D4neg4 (5'TTGCTCATCTTGGAATTTTGCG-3', -156/-177). The PCR was performed in a volume of $100 \mu$ l containing $100 \mathrm{ng}$ genomic DNA, 20 pmol of each primer, $10 \mu \mathrm{l}$ of KOD Dash $10 \times$ PCR Buffer, $200 \mu \mathrm{M}$ each of dNTPs, $10 \%$ dimethylsulfoxide (DMSO), and 2.5 units of KOD Dash (Toyobo, Osaka, Japan). The cycle conditions were $94^{\circ} \mathrm{C}$ for $1 \mathrm{~min}$, then 30 cycles of $94^{\circ} \mathrm{C}$ for $30 \mathrm{~s}, 61^{\circ} \mathrm{C}$ for $2 \mathrm{~s}$, and $74^{\circ} \mathrm{C}$ for $30 \mathrm{~s}$, with a final extension step of $5 \mathrm{~min}$ at $74^{\circ} \mathrm{C}$, in a GeneAmp 2400 Thermocycler (PE Biosystems, Foster City, CA, USA). The PCR products were electrophoresed on a $1.5 \%$ agarose gel containing $1 \times$ Tris-borate/ethylenediamine tetraacetic acid (EDTA) electrophoresis buffer (TBE), and visualized by ethidium bromide staining.

We have done genotyping of nine polymorphisms out of ten in the upstream region of the $D R D 4$ gene previously reported: they are $-809 \mathrm{G}>\mathrm{A},-768 \mathrm{G}>\mathrm{A},-616 \mathrm{C}>\mathrm{G}$, $-603 \mathrm{~T}>\mathrm{del}, \quad-602 \mathrm{G}>\mathrm{del}, \quad-600 \mathrm{G}>\mathrm{C}, \quad-521 \mathrm{C}>\mathrm{T}$, $-376 \mathrm{C}>\mathrm{T}$, and $-291 \mathrm{C}>\mathrm{T}$ (Mitsuyasu et al. 1999). The genotypes of the 173 men from the Self-Defense Forces personnel were determined by direct DNA sequencing. Cycle sequencing was done in a volume of $20 \mu \mathrm{l}$ containing $50-100 \mathrm{ng}$ of concentrated PCR product DNA, with a Microcon YM-100 unit (Millipore, Bedford, MA, USA), with $3.2 \mathrm{pmol}$ of either primer D4neg3 (sense) or D4neg4 (antisense) in the thermocycler with a BigDye Terminator Cycle Sequencing Ready Reaction Kit (PE Biosystems). The cycle sequencing protocol was as recommended by the manufacturer, except that 28 cycles were performed. Sequences were analyzed in an ABI PRISM model 377 DNA Sequencer (PE Biosystems).

The genotypes of the rest of the controls and the schizophrenic patients were determined by the PCR-restriction fragment length polymorphism method, as previously described (Mitsuyasu et al. 1999). The PCR products were digested with NarI, AvaII, BssHII, RsaI, and AvaI to determine the genotypes of the following polymorphisms: $-768 \mathrm{G}>\mathrm{A}, \quad-616 \mathrm{C}>\mathrm{G}, \quad-521 \mathrm{C}>\mathrm{T}, \quad-376 \mathrm{C}>\mathrm{T}$, and $-291 \mathrm{C}>\mathrm{T}$, respectively. Electrophoreses of the digests were carried out on a $2 \%$ agarose gel and visualization was with ethidium bromide staining, except for $A v a \mathrm{I}$ digests, which were electrophoresed on a $3 \%$ agarose gel.

We examined the exon III repeat polymorphism of the DRD4 gene in the Self-Defense Forces personnel using a previously described method (Muramatsu et al. 1996), with slight modification. PCR amplification was performed in a volume of $25 \mu \mathrm{l}$ containing $50 \mathrm{mM} \mathrm{KCl} ; 10 \mathrm{mM}$ Tris- $\mathrm{HCl}$ ( $\mathrm{pH} 9.0)$; 100ng genomic DNA; 10 pmol of each primer (sense primer, 5'-AGGTGGCACGTCGCGCCAAGCT GCA-3'; antisense primer, 5'-TCTGCGGTGGAGTCTG GGGTGGGAG-3'); $100 \mu \mathrm{M}$ each of dATP, dTTP, dCTP, and 7-deaza-2'-deoxyguanosine 5 '-triphosphate; $1.5 \mathrm{mM}$ $\mathrm{MgCl}_{2} ; 10 \%$ DMSO; and 1 unit of Taq DNA polymerase (Promega, Madison, WI, USA). The cycle conditions were $94^{\circ} \mathrm{C}$ for $1 \mathrm{~min}$, then 30 cycles of $94^{\circ} \mathrm{C}$ for $15 \mathrm{~s}, 65^{\circ} \mathrm{C}$ for $30 \mathrm{~s}$, and $72^{\circ} \mathrm{C}$ for $15 \mathrm{~s}$, with a final extension step of $7 \mathrm{~min}$ at $72^{\circ} \mathrm{C}$, in a GeneAmp 2400 thermocycler. The PCR products were electrophoresed on a $3 \%$ agarose gel containing $1 \times$ TBE, and visualized by ethidium bromide staining.

Personality questionnaire

We used the Japanese version of the temperament and character inventory (TCI) (Cloninger et al. 1993), which is a 240-item questionnaire measuring seven dimensions of personality (Kijima et al. 1996). The TCI was developed from the TPQ (Cloninger 1987). The reliability and validity of 
the Japanese version of the TCI have already been verified (Kijima et al. 1996). The 173 individuals from the SelfDefense Forces personnel filled out this personality questionnaire.

\section{Statistical analysis}

Significant differences in genotype and allele frequencies between the schizophrenic patients and control group were evaluated using the $\chi^{2}$ test, with the significance level of 0.05. Associations between the TCI test scores and DRD4 polymorphisms were assessed by the Kruskal-Wallis test or the Mann-Whitney $U$-test. We used the estimate haplotype frequencies $(\mathrm{EH})$ program (Otto 1999) to evaluate linkage disequilibrium.

\section{Results}

Association of polymorphisms with schizophrenia

We determined genotype and allele frequencies of one polymorphism, $-768 \mathrm{G}>\mathrm{A}$, in the negative modulator region, three polymorphisms, $-521 \mathrm{C}>\mathrm{T},-376 \mathrm{C}>\mathrm{T}$, and $-291 \mathrm{C}>\mathrm{T}$, in the cell type-specific promoter region, and one polymorphism, $-616 \mathrm{C}>\mathrm{G}$, between the two regions for the association analysis in the 208 schizophrenic patients and the 210 normal controls. The frequencies of these polymorphisms in the $D R D 4$ gene in the two groups are presented in Table 1. The distribution of these five polymorphisms was in Hardy-Weinberg equilibrium (data not shown). We observed no significant difference in genotype and allele frequencies between the two groups.

There were also no significant differences in these frequencies among schizophrenic subtypes (paranoid, disorganized, catatonic, undifferentiated and residual) (data not shown). Average age of onset did not show any association with the polymorphisms.
Association of polymorphisms with personality traits

To examine the association between personality traits and nine polymorphisms in the upstream region of the $D R D 4$ gene and the exon III repeat polymorphism, we genotyped the subjects from the Self-Defense Forces personnel. As shown in Table 2, the Mann-Whitney $U$-test revealed a significant association between the $-768 \mathrm{G}>\mathrm{A}$ polymorphism and reward dependence scores $(P=0.044)$. Reward dependence scores in subjects with the $-768 \mathrm{G} / \mathrm{A}$ genotype were significantly lower than the scores in those with the $-768 \mathrm{G} / \mathrm{G}$ genotype. The Kruskal-Wallis test revealed significant associations between the $-602 \mathrm{G}>$ del polymorphism and novelty seeking scores $(P=0.037)$. The novelty seeking scores of subjects with the $-602 \mathrm{G} / \mathrm{G}$ genotype were significantly higher than the scores of those with the $-602 \mathrm{del} / \mathrm{del}$ genotype. However, these differences were not significant after Bonferroni correction $(P=0.1095)$.

The exon III repeat polymorphism genotypes were classified into two groups: the short (S) group, containing alleles with two to four repeats and the long (L) group, containing one or two alleles with five to seven repeats. In our subjects, the four-repeat allele was observed most frequently $(80.9 \%)$, followed by the two-repeat allele $(11.8 \%)$. In contrast, the three-repeat $(0.3 \%)$, six-repeat $(1.2 \%)$, and sevenrepeat $(1.2 \%)$ alleles were rare. There was no significant association between any TCI scores and the exon III repeat polymorphism of the $D R D 4$ gene.

\section{Linkage disequilibrium between polymorphisms}

We evaluated linkage disequilibria between the nine polymorphisms, based on the data obtained from the TCI analysis. D' values (i.e., D/Dmax if $\mathrm{D}>0, \mathrm{D} / \mathrm{Dmin}$ if $\mathrm{D}<0$ ) (Hartl and Clark 1997) between polymorphisms were calculated where $P$ values were less than 0.05 by the $\chi^{2}$ test, using the EH program (Otto 1999). D' values were 0.868 between $-521 \mathrm{C}>\mathrm{T}$ and $-291 \mathrm{C}>\mathrm{T}, 0.614$ between $-768 \mathrm{G}>\mathrm{A}$ and $-291 \mathrm{C}>\mathrm{T}, 0.568$ between $-616 \mathrm{C}>\mathrm{G}$ and $-603 \mathrm{~T}>\mathrm{del}$,

Table 1. Genotypes and allele frequencies of $D R D 4$ polymorphisms in schizophrenic patients and controls

\begin{tabular}{|c|c|c|c|c|c|c|c|c|c|c|c|c|}
\hline \multirow{3}{*}{$\frac{\text { Position }}{-291}$} & \multirow{3}{*}{$n$} & \multirow{2}{*}{\multicolumn{3}{|c|}{ Genotype (frequency) }} & \multirow{2}{*}{\multicolumn{2}{|c|}{$\begin{array}{l}\text { Number of allele } \\
\text { (frequency) }\end{array}$}} & \multicolumn{3}{|c|}{ Genotype } & \multicolumn{3}{|c|}{ Allele } \\
\hline & & & & & & & \multirow[t]{2}{*}{ df } & \multirow[t]{2}{*}{$\chi^{2}$} & \multirow[t]{2}{*}{$P$ value } & \multirow[t]{2}{*}{ df } & \multirow[t]{2}{*}{$\chi^{2}$} & \multirow[t]{2}{*}{$P$ value } \\
\hline & & $\mathrm{C} / \mathrm{C}$ & $\mathrm{C} / \mathrm{T}$ & $\mathrm{T} / \mathrm{T}$ & $\mathrm{C}$ & $\mathrm{T}$ & & & & & & \\
\hline Control & 210 & $157(0.748)$ & $49(0.233)$ & 4 (0.019) & $363(0.864)$ & 57 (0.136) & 2 & 0.94 & 0.6264 & 1 & 0.555 & 0.4563 \\
\hline Schizophrenic & 208 & $151(0.726)$ & $50(0.240)$ & $7(0.034)$ & $352(0.846)$ & $64(0.154)$ & & & & & & \\
\hline-376 & & $\mathrm{C} / \mathrm{C}$ & $\mathrm{C} / \mathrm{T}$ & $\mathrm{T} / \mathrm{T}$ & $\mathrm{C}$ & $\mathrm{T}$ & & & & & & \\
\hline Control & 210 & $168(0.800)$ & $41(0.195)$ & $1(0.005)$ & $377(0.898)$ & $43(0.102)$ & 2 & 2.79 & 0.248 & 1 & 2.402 & 0.1212 \\
\hline Schizophrenic & 208 & $179(0.861)$ & $28(0.135)$ & $1(0.005)$ & $386(0.928)$ & $30(0.072)$ & & & & & & \\
\hline-521 & & $\mathrm{C} / \mathrm{C}$ & $\mathrm{C} / \mathrm{T}$ & $\mathrm{T} / \mathrm{T}$ & $\mathrm{C}$ & $\mathrm{T}$ & & & & & & \\
\hline Control & 210 & $25(0.119)$ & $110(0.524)$ & $75(0.357)$ & $160(0.381)$ & $260(0.619)$ & 2 & 2.05 & 0.3584 & 1 & 0.923 & 0.3368 \\
\hline Schizophrenic & 208 & $25(0.120)$ & $122(0.587)$ & $61(0.293)$ & $172(0.413)$ & $244(0.587)$ & & & & & & \\
\hline-616 & & $\mathrm{C} / \mathrm{C}$ & $\mathrm{C} / \mathrm{G}$ & $\mathrm{G} / \mathrm{G}$ & $\mathrm{C}$ & $\mathrm{G}$ & & & & & & \\
\hline Control & 210 & 25 (0.119) & $85(0.405)$ & $100(0.476)$ & $135(0.321)$ & $285(0.679)$ & 2 & 1.18 & 0.5551 & 1 & 1.258 & 0.262 \\
\hline Schizophrenic & 208 & $30(0.144)$ & $89(0.428)$ & $89(0.428)$ & $149(0.358)$ & $267(0.642)$ & & & & & & \\
\hline-768 & & $\mathrm{G} / \mathrm{G}$ & $\mathrm{G} / \mathrm{A}$ & $\mathrm{A} / \mathrm{A}$ & $\mathrm{G}$ & A & & & & & & \\
\hline Control & 210 & $203(0.967)$ & 7 (0.033) & $0(0.000)$ & $413(0.983)$ & 7 (0.017) & 1 & 0.32 & 0.5693 & 1 & 0.319 & 0.5722 \\
\hline Schizophrenic & 208 & $203(0.976)$ & $5(0.024)$ & $0(0.000)$ & $411(0.988)$ & $5(0.012)$ & & & & & & \\
\hline
\end{tabular}

df, Degrees of freedom 
Table 2. Temperament and character inventory (TCI) scores classified by DRD4 polymorphisms

\begin{tabular}{|c|c|c|c|c|c|c|}
\hline Position & Genotype & $n$ & NS & HA & $\mathrm{RD}$ & $\mathrm{P}$ \\
\hline \multirow[t]{4}{*}{-291} & $\mathrm{C} / \mathrm{C}$ & 131 & $18.6 \pm 3.9$ & $16.6 \pm 5.6$ & $16.2 \pm 3.0$ & $5.0 \pm 1.8$ \\
\hline & $\mathrm{C} / \mathrm{T}$ & 38 & $17.6 \pm 4.3$ & $18.7 \pm 5.6$ & $15.1 \pm 3.4$ & $5.0 \pm 1.7$ \\
\hline & $\mathrm{T} / \mathrm{T}$ & 4 & $21.0 \pm 9.0$ & $16.0 \pm 6.1$ & $17.8 \pm 2.2$ & $5.5 \pm 3.1$ \\
\hline & $P^{\mathrm{a}}$ & & 0.604 & 0.060 & 0.090 & 0.622 \\
\hline \multirow[t]{4}{*}{-376} & $\mathrm{C} / \mathrm{C}$ & 133 & $18.7 \pm 4.4$ & $17.0 \pm 5.7$ & $16.0 \pm 3.3$ & $5.0 \pm 1.8$ \\
\hline & $\mathrm{C} / \mathrm{T}$ & 39 & $17.7 \pm 3.3$ & $17.1 \pm 5.9$ & $15.8 \pm 2.7$ & $5.1 \pm 1.8$ \\
\hline & $\mathrm{T} / \mathrm{T}$ & 1 & 15.0 & 22.0 & 17.0 & 4.0 \\
\hline & $P^{\mathrm{a}}$ & & 0.333 & 0.590 & 0.888 & 0.751 \\
\hline \multirow[t]{4}{*}{-521} & $\mathrm{C} / \mathrm{C}$ & 22 & $19.2 \pm 3.7$ & $18.0 \pm 5.8$ & $15.5 \pm 3.1$ & $5.0 \pm 1.6$ \\
\hline & $\mathrm{C} / \mathrm{T}$ & 93 & $18.7 \pm 4.2$ & $16.4 \pm 5.8$ & $16.1 \pm 2.8$ & $5.0 \pm 1.8$ \\
\hline & $\mathrm{T} / \mathrm{T}$ & 58 & $17.8 \pm 4.3$ & $17.7 \pm 5.4$ & $16.0 \pm 3.7$ & $4.9 \pm 1.8$ \\
\hline & $P^{\mathrm{a}}$ & & 0.362 & 0.262 & 0.824 & 0.991 \\
\hline \multirow[t]{4}{*}{-600} & $\mathrm{G} / \mathrm{G}$ & 164 & $18.4 \pm 4.2$ & $17.1 \pm 5.7$ & $15.9 \pm 3.2$ & $5.0 \pm 1.8$ \\
\hline & $\mathrm{G} / \mathrm{C}$ & 6 & $19.8 \pm 5.0$ & $15.2 \pm 3.8$ & $17.0 \pm 1.5$ & $5.2 \pm 1.7$ \\
\hline & $\mathrm{C} / \mathrm{C}$ & 3 & $17.7 \pm 4.2$ & $17.7 \pm 6.7$ & $15.7 \pm 4.5$ & $4.3 \pm 3.1$ \\
\hline & $P^{\mathrm{a}}$ & & 0.626 & 0.613 & 0.696 & 0.932 \\
\hline \multirow{4}{*}{-602} & G/G & 69 & $19.1 \pm 4.8$ & $16.9 \pm 5.9$ & $15.9 \pm 3.0$ & $4.9 \pm 1.9$ \\
\hline & G/del & 72 & $18.6 \pm 3.6$ & $17.5 \pm 4.8$ & $16.1 \pm 3.2$ & $5.2 \pm 1.6$ \\
\hline & $\mathrm{del} / \mathrm{del}$ & 31 & $16.7 \pm 3.7$ & $16.5 \pm 7.0$ & $15.7 \pm 3.3$ & $4.8 \pm 1.9$ \\
\hline & $P^{\mathrm{a}}$ & & 0.037 & 0.854 & 0.604 & 0.690 \\
\hline \multirow[t]{4}{*}{-603} & $\mathrm{~T} / \mathrm{T}$ & 26 & $18.2 \pm 3.7$ & $18.0 \pm 6.0$ & $15.8 \pm 4.2$ & $5.3 \pm 1.5$ \\
\hline & T/del & 72 & $18.6 \pm 3.9$ & $16.9 \pm 5.6$ & $15.5 \pm 2.9$ & $4.9 \pm 1.8$ \\
\hline & del/del & 75 & $18.5 \pm 4.6$ & $16.8 \pm 5.7$ & $16.5 \pm 2.9$ & $4.9 \pm 1.8$ \\
\hline & $P^{\mathrm{a}}$ & & 0.874 & 0.589 & 0.253 & 0.685 \\
\hline \multirow[t]{4}{*}{-616} & $\mathrm{C} / \mathrm{C}$ & 20 & $18.9 \pm 3.9$ & $17.7 \pm 4.8$ & $15.8 \pm 2.9$ & $5.3 \pm 1.8$ \\
\hline & $\mathrm{C} / \mathrm{G}$ & 88 & $18.4 \pm 3.9$ & $17.1 \pm 5.7$ & $15.7 \pm 3.1$ & $4.9 \pm 1.8$ \\
\hline & $\mathrm{G} / \mathrm{G}$ & 65 & $18.4 \pm 4.7$ & $16.8 \pm 6.0$ & $16.4 \pm 3.2$ & $5.0 \pm 1.7$ \\
\hline & $P^{\mathrm{a}}$ & & 0.772 & 0.834 & 0.640 & 0.593 \\
\hline \multirow[t]{3}{*}{-768} & $\mathrm{G} / \mathrm{G}$ & 166 & $18.5 \pm 4.2$ & $16.9 \pm 5.7$ & $16.1 \pm 3.0$ & $5.0 \pm 1.8$ \\
\hline & $\mathrm{G} / \mathrm{A}$ & 7 & $17.3 \pm 3.1$ & $20.3 \pm 3.8$ & $12.6 \pm 4.8$ & $5.4 \pm 2.2$ \\
\hline & $P^{\mathrm{b}}$ & & 0.565 & 0.092 & 0.044 & 0.617 \\
\hline \multirow[t]{4}{*}{-809} & $\mathrm{G} / \mathrm{G}$ & 106 & $18.5 \pm 3.9$ & $17.4 \pm 5.4$ & $15.8 \pm 3.4$ & $4.9 \pm 1.9$ \\
\hline & G/A & 53 & $18.1 \pm 4.3$ & $16.2 \pm 6.2$ & $16.3 \pm 2.9$ & $5.2 \pm 1.4$ \\
\hline & $\mathrm{A} / \mathrm{A}$ & 14 & $19.3 \pm 6.0$ & $17.3 \pm 5.7$ & $16.1 \pm 2.2$ & $5.1 \pm 2.3$ \\
\hline & $P^{\mathrm{a}}$ & & 0.645 & 0.445 & 0.578 & 0.643 \\
\hline \multirow[t]{3}{*}{ Exon III } & S & 151 & $18.4 \pm 4.1$ & $17.1 \pm 5.7$ & $15.9 \pm 3.2$ & $5.0 \pm 1.8$ \\
\hline & $\mathrm{L}$ & 22 & $18.9 \pm 4.6$ & $16.4 \pm 5.9$ & $16.2 \pm 2.7$ & $5.0 \pm 1.6$ \\
\hline & $P^{\mathrm{b}}$ & & 0.653 & 0.627 & 0.891 & 0.835 \\
\hline
\end{tabular}

Scores are shown as means \pm SD. NS, novelty seeking; HA, harm avoidance; RD, reward dependence; $\mathrm{P}$, persistence; S, genotypes with only the short $D R D 4$ alleles with two to four exon III repeats; L, genotypes with one or two copies of the long DRD4 alleles with five to seven exon III repeats

${ }^{a}$ Kruskal-Wallis test

${ }^{\mathrm{b}}$ Mann-Whitney $U$-test

0.441 between $-603 \mathrm{~T}>\mathrm{del}$ and $-602 \mathrm{G}>$ del, 0.335 between $-809 \mathrm{G}>\mathrm{A}$ and $-291 \mathrm{C}>\mathrm{T}, 0.255$ between $-809 \mathrm{G}>\mathrm{A}$ and $-376 \mathrm{C}>\mathrm{T}, 0.200$ between $-616 \mathrm{C}>\mathrm{G}$ and $-602 \mathrm{G}>\mathrm{del}$, 0.173 between $-809 \mathrm{G}>\mathrm{A}$ and $-616 \mathrm{C}>\mathrm{G}, 0.129$ between $-616 \mathrm{C}>\mathrm{G}$ and $-521 \mathrm{C}>\mathrm{T}, 0.086$ between $-521 \mathrm{C}>\mathrm{T}$ and $-376 \mathrm{C}>\mathrm{T}, 0.084$ between $-602 \mathrm{G}>\mathrm{del}$ and $-376 \mathrm{C}>\mathrm{T}$, 0.044 between $-809 \mathrm{G}>\mathrm{A}$ and $-600 \mathrm{G}>\mathrm{C}, 0.043$ between $-603 \mathrm{~T}>$ del and $-600 \mathrm{G}>\mathrm{C}$, and 0.021 between $-376 \mathrm{C}>\mathrm{T}$ and $-291 \mathrm{C}>\mathrm{T}$.

\section{Discussion}

The present study failed to detect a positive association between schizophrenia and five polymorphisms $(-768 \mathrm{G}$ $>\mathrm{A},-616 \mathrm{C}>\mathrm{G},-521 \mathrm{C}>\mathrm{T},-376 \mathrm{C}>\mathrm{T}$, and $-291 \mathrm{C}>\mathrm{T})$ in the upstream region of the DRD4 gene. We could not replicate the previous finding of association between $-521 \mathrm{C}>\mathrm{T}$ and Japanese schizophrenic patients (Okuyama et al. 1999). The allele $\mathrm{C}$ frequencies of controls and schizophrenic patients in the study by Okuyama et al. were 0.41 and 0.48 , respectively, while these frequencies were 0.381 and 0.413 in this study. This discrepancy in the frequencies may be due to regional differences in the subjects. The $D R D 4$ gene shows a high degree of genetic variation in human populations. These include a $-11 \mathrm{C}>\mathrm{T}$, a $+31 \mathrm{G}>\mathrm{C}$ (11Gly>Arg) (Cichon et al. 1995), a 12-base pair (bp) repeat in exon I (Catalano et al. 1993), a 13-bp deletion in exon I (Nothen et al. 1994), a (G)n mononucleotide repeat polymorphism in intron I (Petronis et al. 1994), a +581T $>$ G (194Val>Gly) (Seeman et al. 1994), a 48-bp repeat polymorphism in exon III (Van Tol et al. 1992), and polymorphisms in the upstream region of the gene mentioned in this study (Mitsuyasu et al. 1999). To date, none of these polymorphisms have shown evidence of a strong genetic association with schizophrenia. These results do not support the notion that polymorphisms in the $D R D 4$ gene have a major role in susceptibility to schizophrenia. 
Cloninger et al. (1993) proposed a seven-dimensional personality model, consisting of four temperament scales and three character scales, which can be evaluated by the TCI, an outgrowth of the TPQ (Cloninger 1987). Association of the exon III repeat polymorphism in the DRD4 gene with the personality trait of novelty seeking was reported by two groups in 1996 (Ebstein et al. 1996; Benjamin et al. 1996). After that, four studies replicated this finding (Ono et al. 1997; Ebstein et al. 1997; Noble et al. 1998; Tomitaka et al. 1999), but seven studies failed to replicate the finding. Our findings showed no association between the exon III repeat polymorphism and novelty seeking. The distribution of this polymorphism did not differ from that previously reported in the Japanese population (Muramatsu et al. 1996; Ono et al. 1997; Tomitaka et al. 1999). Because novelty seeking scores are negatively correlated with age (Ebstein and Belmaker 1997), the lack of association in this study may reflect the high mean age, or the sex, of the subjects. The mean ages of the subjects in two previous reports on Japanese population samples (Ono et al. 1997; Tomitaka et al. 1999) were 18.7 and 25.0 years, respectively, and the subjects were women.

The $-768 \mathrm{G}>\mathrm{A}$ polymorphism showed significant association with reward dependence $(P=0.044)$. Subjects with the G/G genotype had a higher reward dependence score than those with the G/A genotype. However, this observation should be interpreted with caution, because the frequency of this polymorphism was rather rare, and there was no significant association of novelty seeking with the $-291 \mathrm{C}>\mathrm{T}$ polymorphism $(P=0.090)$, which showed linkage disequilibrium $\left(\mathrm{D}^{\prime}=0.614\right)$ to the $-768 \mathrm{G}>\mathrm{A}$ polymorphism. Because the $-768 \mathrm{G}>\mathrm{A}$ polymorphism is located within the negative modulator region, the transcription of the DRD4 gene may be affected by this substitution. Noradrenaline was originally hypothesized to be the major neuromodulator of reward dependence (Cloninger 1987). There is close interaction between dopaminergic and adrenergic pathways in the brain (Eshel et al. 1990). The function of recombinant DRD4 expressed in cultured cells was activated by adrenaline, and by noradrenaline in addition to dopamine, indicating that DRD4 may be involved in coordinating signaling among the catecholamine neurotransmitter systems (Hartman and Lanau 1997). These observations suggest that DRD4 could modulate noradrenergic transmission pathways that are related to the personality trait of reward dependence.

Acknowledgments We are grateful to all the medical staff involved in collecting specimens. We especially thank Dr. Nobumitsu Morimoto and Dr. Ichiro Yoshida of Kyushu University, Dr. Jiro Okouchi of the University of Occupational and Environmental Health, and Dr. Masato Nishiwaki of Fukuoka Self-Defense Forces Hospital for their help in initiating this project. This work was supported in part by grants from the Ministry of Education, Science, Sports, and Culture of Japan.

\section{References}

American Psychiatric Association (1994) Diagnostic and statistical manual of mental disorders, 4th edn. American Psychiatric Press, Washington, DC
Benjamin J, Greenberg B, Murphy DL, Li L, Patterson C, Hamer D (1996) Mapping personality traits to genes: population and family association between the D4 dopamine receptor and measures of novelty seeking. Nat Genet 12:81-84

Bouchard TJ Jr (1994) Genes, environment, and personality. Science 264:1700-1701

Catalano M, Nobile M, Novelli E, Nothen MM, Smeraldi E (1993) Distribution of a novel mutation in the first exon of the human dopamine D4 receptor gene in psychotic patients. Biol Psychiatr 34:459-464

Cichon S, Nothen MM, Catalano M, Di Bella D, Maier W, Lichtermann D, Minges J, Albus M, Borrmann M, Franzek E, Strober G, Weigelt B, Korner J, Rietschel M, Propping P (1995) Identification of two novel polymorphisms and a rare deletion variant in the human dopamine D4 receptor gene. Psychiatr Genet 5:97-103

Cloninger CR (1987) A systematic method for clinical description and classification of personality variants. A proposal. Arch Gen Psychiatry 44:573-588

Cloninger CR, Svrakic DM, Przybeck TR (1993) A psychobiological model of temperament and character. Arch Gen Psychiatry 50:975990

Ebstein RP, Novick O, Umansky R, Priel B, Osher Y, Blaine D, Bennett ER, Nemanov L, Katz M, Belmaker RH (1996) Dopamine D4 receptor (D4DR) exon III polymorphism associated with the human personality trait of novelty seeking. Nat Genet 12:78-80

Ebstein RP, Belmaker RH (1997) Saga of an adventure gene: novelty seeking, substance abuse and the dopamine D4 receptor (D4DR) exon III repeat polymorphism. Mol Psychiatry 2:381-384

Ebstein RP, Nemanov L, Klotz I, Gritsenko I, Belmaker RH (1997) Additional evidence for an association between the dopamine D4 (D4DR) exon III repeat polymorphism and the human personality trait of novelty seeking. Mol Psychiatry 2:472-477

Eshel G, Ross SB, Kelder D, Edis LEM, Jackson DM (1990) Alpha1 (but not alpha2)-adrenoceptor agonists in combination with the dopamine D2 agonist quinpirole produce locomotor stimulation in dopamine-depleted mice. Pharmacol Toxicol 67:123-131

Hartl DL, Clark AG (1997) Principles of population genetics, 3rd edn. Sinauer Associates, Inc., Sunderland

Hartman DS, Lanau F (1997) Diversity of dopamine receptors: new molecular and pharmacological developments. Pol J Pharmacol Pharm 49:191-199

Kamakura S, Iwaki A, Matsumoto M, Fukumaki Y (1997) Cloning and characterization of the 5'-flanking region of the human dopamine D4 receptor gene. Biochem Biophys Res Commun 235:321-326

Kijima N, Saito R, Suzuki M, Yoshino A, Ono Y, Kato M, Kitamura T (1996) Cloninger's seven-factor model of temperament and character and Japanese version of temperament and character inventory (TCI) (in Japanese). Arch Psychiatr Diagn Clin Eval 7:379399

Lahiri DK, Nurnberger JI Jr (1991) A rapid non-enzymatic method for the preparation of HMW DNA from blood for RFLP studies. Nucleic Acids Res 19:5444

Mitsuyasu H, Ozawa H, Takeda Y, Fukumaki Y (1999) Novel polymorphisms in the upstream region of the human dopamine D4 receptor (DRD4) gene. J Hum Genet 44:416-418

Muramatsu T, Higuchi S, Murayama M, Matsushita S (1996) Association between alcoholism and the dopamine D4 receptor gene. J Med Genet 33:113-115

Noble EP, Ozkaragoz TZ, Ritchie TL, Zhang X, Belin TR, Sparkes RS (1998) D2 and D4 dopamine receptor polymorphisms and personality. Am J Med Genet 81:257-267

Nothen MM, Cichon S, Hemmer S, Hebebrand J, Remschmidt H, Lehmkuhl G, Poustka F, Schmidt M, Catalano M, Fimmers R, Korner J, Rietschel M, Propping P (1994) Human dopamine D4 receptor gene: frequent occurrence of a null allele and observation of homozygosity. Hum Mol Genet 12:2207-2212

Okuyama Y, Ishiguro H, Toru M, Arinami T (1999) A genetic polymorphism in the promoter region of DRD4 associated with expression and schizophrenia. Biochem Biophys Res Commun 258:292-295

Ono Y, Manki H, Yoshimura K, Muramatsu T, Mizushima H, Higuchi S, Yagi G, Kanba S, Asai M (1997) Association between dopamine D4 receptor (D4DR) exon III polymorphism and novelty seeking in Japanese subjects. Am J Med Genet 74:501-593 
Otto J (1999) Analysis of human genetic linkage. The Johns Hopkins University Press, Baltimore

Paterson AD, Sunohara GA, Kennedy JL (1999) Dopamine D4 receptor gene: novelty or nonsense? Neuropsychopharmacology 21:3-16

Petronis A, Ohara K, Barr CL, Kennedy JL, Van Tol HHM (1994) (G)n-mononucleotide polymorphism in the human DRD4 gene. Hum Genet 93:719

Seeman P, Guan HC, Van Tol HHM (1993) Dopamine D4 receptors elevated in schizophrenia. Nature 365:441-445

Seeman P, Ulpian C, Chouinard G, Van Tol HHM, Dwosh H, Lieberman JA, Siminovitch K, Liu ISC, Waye J, Voruganti P, Hudson C, Serjeant GR, Masibay AS, Seeman MV (1994) Dopamine D4 receptor variant, D4 glycine194, in Africans, but not in Caucasians: no association with schizophrenia. Am J Med Genet 54:384-390

Stefanis NC, Bresnick JN, Kerwin RW, Schofield WN, McAllister G (1998) Elevation of D4 dopamine receptor mRNA in postmortem schizophrenic brain. Brain Res Mol Brain Res 53:112-119
Tarazi FI, Baldessarini RJ (1999) Dopamine D4 receptors: significance for molecular psychiatry at the millennium. Mol Psychiatry 4:529538

Tomitaka M, Tomitaka S, Otuka Y, Kim K, Matuki H, Sakamoto K, Tanaka A (1999) Association between novelty seeking and dopamine receptor D4 (DRD4) exon III polymorphism in Japanese subjects. Am J Med Genet 88:469-471

Van Tol HH, Bunzow JR, Guan HC, Sunahara RK, Seeman P, Niznik HB, Civelli O (1991) Cloning of the gene for a human dopamine D4 receptor with high affinity for the antipsychotic clozapine. Nature 350:610-614

Van Tol HHM, Wu CM, Guan HC, Ohara K, Bunzow JR, Civelli O, Kennedy J, Seeman P, Niznik HB, Jovanovic V (1992) Multiple dopamine D4 receptor variants in the human population. Nature 358:149-152 